\title{
Socioscientific Issues within Science Education and their Role in Promoting the Desired Citizenry
}

\author{
TBM Chowdhury*, Jack Holbrook and Miia Rannikmäe
}

Centre for Science Education, University of Tartu, Tartu, Estonia

*Corresponding author: tapashib@ut.ee

\section{ABSTRACT}

This article sought to give an overview of different interpretations and characterizations of socioscientific issues (SSIs) by identifying single entities that could form components of SSI and give examples of where single entities were combined to involve SSI in enhancing scientific literacy. Through a narrative literature review, the article examined how SSI within science education could contribute to promoting citizenship through personally responsible, participatory, justice oriented, and politically concerned reflections to support the development of the desired citizenry. The significance of this article lies on the synthesis of literature on the contribution and barriers of SSI in promoting the desired citizenry.

KEY WORDS: justice-oriented citizens; participatory citizens; personally responsible citizens; politically concerned citizens; socioscientific issue

\section{INTRODUCTION}

$\Lambda$ ccepting the role of science education as enhancing scientific literacy (Norris and Phillips, 2003), implies the involvement of students in learning which goes beyond cognitive capabilities, where the inclusion of socioscientific issues (SSI) promotes a wider literacy dimension leading to better-informed citizens (Sakschewski et al., 2014). Nevertheless, it can be argued that an informed citizenry is not sufficient. The desired citizenry also needs to be participatory and hence allowing citizens to play an active role in the resolving of issues within the society.

This paper reviews the attribute of SSI, which recognize that science education is more than promoting cognitive development within a science frame and sees science and society interactions providing a meaningful context for learning. Gilbert (2006) put forward four models for ascertaining the meaning of context in chemistry education, which are seen as equally applicable to science education in general. SSI provides a meaningful frame to promote each of these models in that:

a. It needs to involve the application of acquired science concepts to the socioscientific context

b. The science conceptualizations are directly embedded in discussing or debating the issue situation

c. The mental activity involves the putting forward of arguments in favor of a point of view and possibly refuting the opinions of others, all based on informed opinions

d. SSI, in providing the socioscientific context, is directly identifying the social circumstance.

The intention of this paper was to go beyond the proposed importance of SSI, indicated by Zeidler (2014), in his review, adding emphasis to the incorporation of SSI to promote the desired citizenry.

The concept of SSI was developed as a bridge between science and its interactions within the society (Sadler, 2004), although interrelating the teaching of science with the society is not new. Over 100 years ago, Dewey (1910) suggested that science in school should incorporate social and moral dimensions. He added that without acknowledging science as a process of metacognition, teaching science remains insufficient, only equipped with "ready-made material" (Dewey, 1910).

The science, technology, and society (STS) movement (Aikenhead, 1992; Rubba, 1991) was an attempt to interrelate society with science education through a problem-solving approach even before the promoting of responsible citizenry became a curriculum focus. In seeing the need to interrelate scientific learning with social considerations, the prerequisites of a STS curriculum were stated as:

- Identifying the science links related to social concerns

- Allowing analysis of issues in response to beliefs and values

- Using scientific problem-solving skills, and

- Determining the most effective means to solve those (Ramsey, 1989).

However, although STS education emphasized the impact of decisions in science and technology, this was more problem solving, placing less emphasis on ethical or moral issues, or even character development (Shamos, 1995). In fact, STS has been referred to as an "underdeveloped idea in search of a theory" (Zeidler et al., 2005). 
Further elaboration of the STS movement led to recognizing the value of inclusion of SSI in science education. SSI seems to be first introduced by Fleming (1986), who used the term for science and technology-related social issues. Later, the concept incorporated wider components under its umbrella such as "controversial SSIs" (Kolstø, 2001), focusing on typical examples of local disagreements, covered by the media, deeply rooted in daily life, science-related situations. Its significance arises through involving students in putting forward informed opinions, based on an appropriate conceptualization of the related science, to seek to resolve issues incorporating a range of social factors, seeing this form of enhanced scientific literacy as promoting a more informed citizenry.

To determine how SSI is characterized and the contribution SSI makes to the need to promote citizenship, this article puts forward two research questions:

1. How does the literature define and characterize SSI within science education?

2. What contribution can SSI make toward promoting the desired citizenry?

\section{LITERATURE REVIEW}

\section{How does the Literature Define SSI?}

Inevitably, when referring to SSI, the literature struggles with the English interpretation of the terms "problem" and "issue." Whereas a problem is expected to be identified with the determination of a solution, an issue tends to be broader and the matter tends to be resolved, based on meaningful or accepted criteria, which may or may not be constant and accepted by all which may require discussion, debate, or argumentation
(Zeidler et al., 2009). Thus, SSI is expected to relate explicitly to an issue (Yahaya et al., 2016) rather than just one problem, although in some cases, reference is made to "open-ended problems" (Khishfe, 2017; Sadler, 2011a). This contrasts with problem-based learning (PBL) and inquiry-based science education in which the focus is on attaining a conclusion that sees the evidence seeking a specific solution.

The general picture of SSI is that it relates to an issue, or several issues at a time, involving aspects, such as those indicated in Table 1.

\section{Dimensions of SSI}

Although Table 1 refers to single perspectives associated with SSI, these by themselves rarely define SSI, and SSI normally possesses multiple perspectives.

The issues and potential courses of action associated with the issues are influenced by a variety of social factors, including politics, economics, and ethics (Sadler, 2011b, p. 4).

In Table 1, the controversial aspect of SSI, mentioned by Yahaya et al. (2016), leads to SSI having no definite answers, even in a specific situation. The controversial aspect can relate to there being different viewpoints, or opinions associated with a single issue, or multiple perspectives of an issue. Dearden (1981) explained a controversial issue within science curriculum as:

A matter is controversial if contrary views can be held on it without those views being contrary to reason. By "reason" here is not meant something timeless and unhistorical, but

\section{Table 1: Features specified in the literature associated with SSI}

\begin{tabular}{|c|c|c|c|}
\hline No. & SSI aspect & Simple description of the aspect related to science education & Reference \\
\hline 1. & Controversial & $\begin{array}{l}\text { SSI usually addresses controversial situations, which can include socially significant and science } \\
\text { linked issues involving, for example, cultural, ethical, moral, traditional, economic, political, or } \\
\text { spiritual perspectives }\end{array}$ & $\begin{array}{l}\text { (Yahaya et al., } \\
\text { 2016) }\end{array}$ \\
\hline 2. & Ill-structured & Often a socioscientific issue is not well articulated and the procedure and focus can be ill-structured & $\begin{array}{l}\text { (Zeidler and } \\
\text { Sadler, 2007) }\end{array}$ \\
\hline 3. & Real-life orientation & $\begin{array}{l}\text { SSI represents real issues faced by scientists and other citizens, which can be focused at a local, } \\
\text { national, or global level. The SSI is seen as real, even in the context of classroom explorations }\end{array}$ & $\begin{array}{l}\text { (Böttcher and } \\
\text { Meisert, 2013) }\end{array}$ \\
\hline 4. & Moral reasoning aspect & $\begin{array}{l}\text { SSI involves the deliberate use of conceptual science related to social expectations, involving a } \\
\text { degree of moral reasoning from a student's perspective }\end{array}$ & $\begin{array}{l}\text { (Zeidler and } \\
\text { Nichols, 2009) }\end{array}$ \\
\hline 5. & Ethical aspect & When an SSI includes ethical aspects, these become a major focus of the discussion or debate & (Lee et al., 2012) \\
\hline 6. & Value laden & $\begin{array}{l}\text { SSI is often value laden and requires students' recognition, leading to an establishment of their } \\
\text { values }\end{array}$ & (Tomas, 2011) \\
\hline 7. & Scientific context & $\begin{array}{l}\text { SSI seeks to involve students in decision making regarding current social issues embedded in a } \\
\text { context, the resolution of which depends on the inclusion of meaningfully conceptualized science }\end{array}$ & $\begin{array}{l}\text { (Linder et al., } \\
\text { 2011) }\end{array}$ \\
\hline 8. & Contextual learning & SSI provides an environment for contextual dimensions of learning experiences & $\begin{array}{l}\text { (Sadler et al., } \\
\text { 2017) }\end{array}$ \\
\hline 9. & Curriculum connectedness & SSI relates to the curriculum and its intended learning, even if it is not specifically stipulated. & $\begin{array}{l}\text { (Klosterman and } \\
\text { Sadler, 2010) }\end{array}$ \\
\hline 10. & Argumentation aspect & $\begin{array}{l}\text { An SSI needs to be resolved and thus provides ideal grounds for the use, or development of, } \\
\text { argumentation skills within the fame of a discussion or debate, etc. The argumentation aspect thus } \\
\text { makes SSI activities strongly student-involved }\end{array}$ & $\begin{array}{l}\text { (Uskola et al., } \\
\text { 2010) }\end{array}$ \\
\hline
\end{tabular}


the body of public knowledge, criteria of truth, critical standards, and verification procedures which at any given time has been so far developed (p. 38).

Being controversial in nature, SSI reveals multiple values from several parts of society. Halim and Saat (2017) explain this disclosure of multiple values as:

Those issues on which our society is clearly divided and significant groups within society advocate conflicting explanations or solutions based on alternative values (p. 9).

\section{What Contribution can SSI make Toward Promoting the Desired Citizenry?}

The above components and dimensions of SSI are recognized as forming multiple perspectives enabling support for the varied aspects of the nature of science education in enhancing scientific literacy within society. The nature of science education can be considered as composed of three key aspects - the nature of science and personal and social development attributes (Holbrook and Rannikmäe, 2007). In line with this, and in particular the personal and social development, a number of articles in the science education literature draw attention to the need to develop students' capabilities to become good citizens (Lee et al., 2012; Vesterinen et al., 2014; Vesterinen et al., 2016). As a specific component of this, Hazelkorn et al. (2015) interpreted this to indicate the need for students to become active, engaged citizens as part of a learning continuum, starting from pre-school, while (Linder et al., 2007; Vesterinen et al., 2016) put more emphasis on science education contributing to the development of an "informed citizenry." Kerr (1999) stresses the inevitable need for citizenship education in the school curriculum.

Westheimer and Kahne (2004), seek to clarify the actual connection between science education and citizenry and put forward three key attributes expected of students where citizenry is seen as an important target:

- Personally responsible,

- Participatory, and

- Justice oriented.

These conceptions are amplified further to appreciate an intended potential role and importance of SSI in striving to promote good, actively engaged, and informed citizens within science education.

\section{Personally Responsible Citizen}

Westheimer and Kahne (2004) suggest the core assumption of personally responsible citizens is established by their ability to "resolve" social problems and improve society by having good characteristics such as honesty, responsibility, and being a law-abiding member of the society.

In fact, with respect to SSI, the above can appropriately be amended to relate to social issues and how these are handled in a responsible manner. If so, to promote personally responsible citizens, SSI surely can play a major role even going beyond ethical perceptive (Barrett and Nieswandt, 2010). SSI provides an opportunity for students to confront controversial issues, which facilitate students in acquiring the understanding and skills needed to become responsible and effective members of society (Oulton et al., 2004). Zeidler (2014), in his review, also recognizes that SSI can promote personally responsible citizenry, reasoning that SSI creates an environment for community engagement inside and outside the classroom, which he suggests is essential for promoting a responsible citizen.

\section{Participatory Citizen}

Westheimer and Kahne (2004) characterize participatory citizens according to their ability to participate actively and take up a leadership role, if necessary, within the community. Vesterinen et al. (2016) indicate that participating in SSIrelated situations has an effect on students' active engagement within the society, which makes students more likely to participate in political and civic activities as adults (Kerr et al., 2001). Sadler (2009) adds to the idea that SSI provides educational opportunities for reasoning and critical thinking, both important in science education and necessary for civic participation. In addition, SSI provides opportunities for students to be involved in contextualized argumentation in science education, suggesting this creates an instance of "education for participating citizenship" (Zeidler and Sadler, 2007, 2010).

\section{Justice Oriented Citizens}

Key criteria for justice-oriented citizenry are defined by the ability and willingness to question, debate, and change established systems and structures that reproduce patterns of injustice over time (Westheimer and Kahne, 2004). Althof and Berkowitz (2006) add that justice-oriented citizens possess the ability:

...to critically assess social, political, and economic structures and to explore collective strategies for change and the remedy of problems (p. 507).

Including SSI in science, teaching gives value to promoting justice-oriented citizens by create occasions whereby students can develop a critical appreciation of issues of right and wrong, justice, fairness, rights, and obligations in society (Oulton et al., 2004). Reiss (2007) went further and suggested that the aim of science education is also to strive for social justice, while recent literature stresses the fact that SSI, through its controversial nature, holds the potential to achieve this goal (Al Badri, 2016).

\section{A $4^{\text {th }}$ Perception - Politically Concerned Citizens}

Besides the above perceptions of responsible citizens, students' involvement and ensuring justice, in a later paper, Kahne and Westheimer (2006) indicate an interest in political situations as a further major factor of citizenry. In fact, a number of articles draw attention to the fact that youth are especially interested in SSI addressing political actions (Owens et al., 2017; Yahaya et al., 2016; Zeidler et al., 2005).

The literature implies that SSI, involving direct forms of lifestyle politics and community-based work, provides an educational 


\section{Table 2: Attributes of SSI and their value to promote the desired citizenry}

\section{Attribute 1: Socially embedded science contexts oriented to local, national, and global issues:}

Simple description - Involves students in current social issues embedded, the resolution of which depends on the inclusion of meaningfully conceptualized science providing scientific literacy and promoting understanding of nature of science, making science education more relevant and significant for students toward their lives (Bossér and Lindahl, 2017; Cinici, 2016; Herman, 2018; Kahn and Zeidler, 2016; Khishfe et al., 2017)

- Provides an environment for contextual dimensions of learning experiences including societal aspects to the learning experience (Gresch et al., 2017; Ozturk and Yilmaz-Tuzun, 2017; Tidemand and Nielsen, 2017; Zangori et al., 2017)

- Involves issues faced by scientists and other citizens seen as real, which can be focused at a local, national, or global level. The orientation is seen as real, even in the context of classroom explorations (Herman et al., 2018)

Contribution to the promotion of the desired citizenry

Barriers in contribution to the promotion of the desired citizenry

- Xiao (2018) recognized that one of the most emphasized goals of school science was to prepare students for their everyday life, which resulted in the shift of emphasis toward preparing citizens with adequate literacy and sense of responsibility

- One major attempt to achieve this goal was to incorporate SSI in the curriculum to promote informed decision making among the students regarding their everyday life issues, providing them with a socially embedded scientific context, which encompassed local, national or global issues

- Hsu and Lin, 2017 emphasized that solely science content-oriented teaching with the major focus given only on well-structured question solving, where the key emphasis needed to be given to students' engagement on scientific process embedded in authentic problems, with opportunities to use their science knowledge and skills, led to the failure to promote informed decision-making skills through SSI

- Shea et al. (2015) recognize this as a major risk of inadequate instructions of SSI in science classrooms, leading toward students being unprepared to deal with authentic or science issues related to everyday life.

\section{Attribute 2: Perception of complexity in diverse values, ethics, and morals}

Simple description - Addresses controversial situations, which can include socially significant and science-linked issues involving, for example, cultural, ethical, moral, traditional, economic, political, or spiritual perspectives (Cinici, 2016; Yahaya et al., 2016)

- SSI is often value laden and requires students' recognition, leading to an establishment of their values (Yacoubian and Khishfe, 2018)

- When an ethical aspect is included, it becomes a major focus of the discussion or debate (Ozturk and Yilmaz-Tuzun, 2017)

- Involves the deliberate use of conceptual science related to social expectations, involving a degree of moral reasoning from a student's perspective (Namdar and Shen, 2016)

Contribution to the promotion of the

- Making informed decisions, being considered as one of the main concerns regarding preparing the desired citizenry, Karahan and Roehrig (2017) identify the criteria of an informed decision as the ability to assess the risks and benefits of alternative solutions, intriguing questions and assessing the trustworthiness of the evidence and counter evidence

- This requires students to deal with complex issues, recognizing the diverse values, ethics, and moral standpoints

Barriers in contribution - SSI, being very much oriented to personal and social viewpoints, and inadequate content background, ill-instruction, frequent to the promotion of a desired citizenry use of a heuristic method, and cultural diversity, may lead to the decision made based on socioscientific reasoning differing from person to person in terms of their reflective judgment and hence their activities based on the decision may not be similar (Bossér and Lindahl, 2017; Cinici, 2016; Grace et al., 2015; Gresch et al., 2017; Shea et al., 2015; Tidemand \& Nielsen, 2017)

\section{Attribute 3: Promoting student participation through an ill-structured cross-curriculum context}

\begin{tabular}{|c|c|}
\hline descrip & $\begin{array}{l}\text { - Often a socioscientific issue is not well articulated and the procedure and focus can be ill-structured (Yahaya et al., 2016) } \\
\text { - Requires literacy over a spectrum of issues to engage in argumentation, discussion, decision-making process (Dawson, 2015; } \\
\text { Herman et al., 2018; Shea et al., 2015) } \\
\text { - The issue needs to be resolved and thus provides ideal grounds for the use, or development of, argumentation skills within } \\
\text { the frame of decision making, discussion or debate, etc. The argumentation aspect thus makes SSI activities strongly student- } \\
\text { involved (Dawson, 2015; Sadler et al., 2016; Wang et al., 2017) }\end{array}$ \\
\hline $\begin{array}{l}\text { Contribution to the } \\
\text { promotion of the } \\
\text { desired citizenry }\end{array}$ & $\begin{array}{l}\text { - While making consensus decisions, SSI is often recognized as ill-structured and open-ended without aiming at a single } \\
\text { solution, rather looking at the issue from several perspectives, which provides the students with opportunities to enact their } \\
\text { argumentation skills through discussion, debate or decision making through a cross-curriculum approach (Grace et al., 2015) }\end{array}$ \\
\hline $\begin{array}{l}\text { Barriers in contribution } \\
\text { to the promotion of the } \\
\text { desired citizenry }\end{array}$ & $\begin{array}{l}\text { - Kilinc et al. (2017) recognize that underdeveloped epistemologies and unclear teaching goals being the key challenges, lack } \\
\text { of expertise, time, pedagogical content knowledge, and communication skills to manage unpredictability of controversial } \\
\text { SSIs, overloaded and examination-oriented curriculum and lack of support from stakeholders result in teachers' frequent } \\
\text { use of teacher-oriented discourse in SSI activities. This leads to the gap between the expectation and the results of including } \\
\text { socioscientific issues in curriculum }\end{array}$ \\
\hline
\end{tabular}

SSI: Socioscientific issues

setting emphasizing the development of self-expression and self-actualization in students (Dalton, 2008; Kahne and Westheimer, 2006; Quintelier, 2007; Sloam, 2014; Zukin et al., 2006).

\section{DISCUSSION}

Based on the literature, three major attributes associated with SSI were identified, indicating a contribution and barriers toward the preparation of the desired citizenry through science education were identified. These were as amplified in Table 2.

\section{CONCLUSION}

The concept of SSI has been evolving and merging more and more potential areas in which it can play a role enabling students to achieve the goals of science education. This article 
provides an overview of aspects and dimensions of SSI, which can be summarized as SSI is controversial in nature, lies in a social context but having a scientific consideration, requires multiple considerations such as - moral, ethical, cultural, traditional, economic, political, and environmental and is intended to result in student gains in undertaking decision making, enhancing scientific literacy, as well as enabling intellectual growth, moral development, and community engagement, in local, social, and global contexts.

This study provides a procedural link to utilize the aspects and dimensions of SSI to promote the desired citizenry and draws attention to the scope for research in overcoming the barriers of implementing SSI.

\section{REFERENCES}

Aikenhead, G. (1992). The integration of STS into science education. Theory Into Practice, 31(1), 27-35.

Al Badri, S. (2016). Teaching controversial issues in the classroom. Citizenship Education Research Journal, 5(1), 73-83.

Althof, W., \& Berkowitz, M.W. (2006). Moral education and character education: Their relationship and roles in citizenship education. Journal of Moral Education, 35(4), 495-518.

Barrett, S.E., \& Nieswandt, M. (2010). Teaching about ethics through socioscientific issues in physics and chemistry: Teacher candidates' beliefs. Journal of Research in Science Teaching, 47(4), 380-401.

Bossér, U., \& Lindahl, M. (2017). Students' positioning in the classroom: A study of teacher-student interactions in a socioscientific issue context. Research in Science Education, 49, 371-390

Böttcher, F., \& Meisert, A. (2013). Effects of direct and indirect instruction on fostering decision-making competence in socioscientific issues. Research in Science Education, 43(2), 479-506.

Cinici, A. (2016). Balancing the pros and cons of GMOs: Socio-scientific argumentation in pre-service teacher education. International Journal of Science Education, 38(11), 1841-1866.

Dalton, R.J. (2008). The Good Citizen: How a Younger Generation is Reshaping American Politics. California, United States: Sage.

Dawson, V. (2015). Western Australian high school students' understandings about the socioscientific issue of climate change. International Journal of Science Education, 37(7), 1024-1043.

Dearden, R.F. (1981). Controversial issues and the curriculum. Journal of Curriculum Studies, 13(1), 37-44.

Dewey, J. (1910). Science as subject-matter and as method. Science, 31(787), 121-127.

Fleming, R. (1986). Adolescent reasoning in socio-scientific issues Part II: Nonsocial cognition. Journal of Research in Science Teaching, 23(8), 689-698.

Gilbert, J.K. (2006). On the nature of "context" in chemical education. International Journal of Science Education, 28(9), 957-976.

Grace, M., Lee, Y.C., Asshoff, R., \& Wallin, A. (2015). Student decisionmaking about a globally familiar socioscientific issue: The value of sharing and comparing views with international counterparts. International Journal of Science Education, 37(11), 18550-1874.

Gresch, H., Hasselhorn, M., \& Bögeholz, S. (2017). Enhancing decisionmaking in STSE education by inducing reflection and self-regulated learning. Research in Science Education, 47(1), 95-118.

Halim, M., \& Saat, R.M. (2017). Exploring students' understanding in making a decision on a socioscientific issue using a persuasive graphic organiser. Journal of Baltic Science Education, 16(5), 813.

Hazelkorn, E., Ryan, C., Beernaert, Y., Constantinou, C.P., Deca, L., Grangeat, M., Karikorpi, M., Lazoudis, A., Casulleras, R.P., \& Welzel, M. (Eds.). (2015). Science Education for Responsible Citizenship: Report to the European Commission of the Expert Group on Science Education. Brussels, Belgium: Publications Office of the European Union.

Herman, B.C. (2018). Students' environmental NOS views, compassion, intent, and action: Impact of place-based socioscientific issues instruction. Journal of Research in Science Teaching, 55(4), 600-638.

Herman, B.C., Zeidler, D.L., \& Newton, M. (2018). Students' emotive reasoning through place-based environmental socioscientific issues. Research in Science Education, 1-29.

Holbrook, J., \& Rannikmäe, M. (2007). The nature of science education for enhancing scientific literacy. International Journal of Science Education, 29(11), 1347-1362.

Hsu, Y.S., \& Lin, S.S. (2017). Prompting students to make socioscientific decisions: Embedding metacognitive guidance in an e-learning environment. International Journal of Science Education, 39(7), 964-979.

Kahn, S., \& Zeidler, D.L. (2016). A case for the use of conceptual analysis in science education research. Journal of Research in Science Teaching, 54(4), 538-551.

Kahne, J., \& Westheimer, J. (2006). The limits of political efficacy: Educating citizens for a democratic society. PS: Political Science and Politics, 39(2), 289-296.

Karahan, E., \& Roehrig, G. (2017). Secondary school students' understanding of science and their socioscientific reasoning. Research in Science Education, 47(4), 755-782.

Kerr, D. (1999). Changing the political culture: The advisory group on education for citizenship and the teaching of democracy in schools. Oxford Review of Education, 25(1-2), 275-284.

Kerr, D., Lines, A., Blenkinsop, S., \& Schagen, I. (2001). Citizenship and Education at Age 14: A Summary of the International Findings and Preliminary Results for England, IEA International Citizenship Education Study. England, Slough: NFER.

Khishfe, R. (2017). Consistency of nature of science views across scientific and socio-scientific contexts. International Journal of Science Education, 39(4), 403-432.

Khishfe, R., Alshaya, F.S., BouJaoude, S., Mansour, N., \& Alrudiyan, K.I. (2017). Students' understandings of nature of science and their arguments in the context of four socio-scientific issues. International Journal of Science Education, 39(3), 299-334.

Kilinc, A., Demiral, U., \& Kartal, T. (2017). Resistance to dialogic discourse in SSI teaching: The effects of an argumentation-based workshop, teaching practicum, and induction on a preservice science teacher. Journal of Research in Science Teaching, 54(6), 764-789.

Klosterman, M.L., \& Sadler, T.D. (2010). Multi-level assessment of scientific content knowledge gains associated with socioscientific issues-based instruction. International Journal of Science Education, 32(8), 1017-1043.

Kolstø, S.D. (2001). Scientific literacy for citizenship: Tools for dealing with the science dimension of controversial socioscientific issues. Science Education, 85(3), 291-310.

Lee, H., Chang, H., Choi, K., Kim, S.W., \& Zeidler, D.L. (2012). Developing character and values for global citizens: Analysis of pre-service science teachers' moral reasoning on socioscientific issues. International Journal of Science Education, 34(6), 925-953.

Linder, C., Östman, L., \& Wickman, P.O. (2007). Promoting Scientific Literacy: Science Education Research in Transaction. Uppsala, Sweden: Linnaeus Tercentenary Symposium.

Linder, C., Östman, L., Roberts, D.A., Wickman, P.O., Erickson, G., \& MacKinnon, A. (2011). Exploring the Landscape of Scientific Literacy. New York: Routledge. pp. 1-302.

Namdar, B., \& Shen, J. (2016). Intersection of argumentation and the use of multiple representations in the context of socioscientific issues International Journal of Science Education, 38(7), 1100-1132.

Norris, S.P., \& Phillips, L.M. (2003). How literacy in its fundamental sense is central to scientific literacy. Science Education, 87(2), 224-240.

Oulton, C., Day, V., Dillon, J., \& Grace, M. (2004). Controversial issuesteachers' attitudes and practices in the context of citizenship education. Oxford Review of Education, 30(4), 489-507.

Owens, D.C., Sadler, T.D., \& Zeidler, D.L. (2017). Controversial issues in the science classroom. Phi Delta Kappan, 99(4), 45-49.

Ozturk, N., \& Yilmaz-Tuzun, O. (2017). Preservice science teachers' epistemological beliefs and informal reasoning regarding socioscientific issues. Research in Science Education, 47(6), 1275-1304

Quintelier, E. (2007). Differences in political participation between young 
and old people. Contemporary Politics, 13(2), 165-180.

Ramsey, J.M. (1989). A curricular framework for community-based STS issue instruction. Education and Urban Society, 22(1), 40-53.

Reiss, M. (2007). What should be the aim (s) of school science education. The Re-Emergence of Values in Science Education. Boston: Sense Publishers. pp. 13-28.

Rubba, P.A. (1991). Integrating STS into school science and teacher education: Beyond awareness. Theory into Practice, 30(4), 303-308.

Sadler, T.D. (2004). Informal reasoning regarding socioscientific issues: A critical review of research. Journal of Research in Science Teaching, 41(5), 513-536.

Sadler, T.D. (2009). Situated learning in science education: Socio-scientific issues as contexts for practice. Studies in Science Education, 45(1), 1-42.

Sadler, T.D. (2011a). Situating socio-scientific issues in classrooms as a means of achieving goals of science education. In: Sadler, T.D., (Ed.), Socio-scientific Issues in the Classroom: Teaching, Learning and Research. Netherlands: Springer. pp. 1-9.

Sadler, T.D. (2011b). Socio-scientific Issues in the Classroom: Teaching, Learning and Research. Netherlands: Springer.

Sadler, T.D., Foulk, J.A., \& Friedrichsen, P.J. (2017). Evolution of a model for socio-scientific issue teaching and learning. International Journal of Education in Mathematics Science and Technology, 5(2), 75-87.

Sadler, T.D., Romine, W.L., \& Topçu, M.S. (2016). Learning science content through socio-scientific issues-based instruction: A multi-level assessment study. International Journal of Science Education, 38(10), 1622-1635.

Sakschewski, M., Eggert, S., Schneider, S., \& Bögeholz, S. (2014). Students' socioscientific reasoning and decision-making on energy-related issuesdevelopment of a measurement instrument. International Journal of Science Education, 36(14), 2291-2313.

Shamos, M.H. (1995). The Myth of Scientific Literacy. United States: Rutgers University Press.

Shea, N.A., Duncan, R.G., \& Stephenson, C. (2015). A tri-part model for genetics literacy: Exploring undergraduate student reasoning about authentic genetics dilemmas. Research in Science Education, 45(4), 485-507

Sloam, J. (2014). New voice, less equal: The civic and political engagement of young people in the United States and Europe. Comparative Political Studies, 47(5), 663-688.

Tidemand, S., \& Nielsen, J.A. (2017). The role of socioscientific issues in biology teaching: From the perspective of teachers. International Journal of Science Education, 39(1), 44-61.

Tomas, L. (2011). Merging fact with fiction: Developing students' scientific literacy through story writing on a socioscientific issue.

Curriculum Leadership, 9(5), Article 1.

Uskola, A., Maguregi, G., \& Jiménez-Aleixandre, M. (2010). The use of criteria in argumentation and the construction of environmental concepts: A university case study. International Journal of Science Education, 32(17), 2311-2333.

Vesterinen, V.M., Manassero-Mas, M.A., \& Vázquez-Alonso, Á. (2014). History, philosophy, and sociology of science and science-technology-society traditions in science education: Continuities and discontinuities. In: International Handbook of Research in History, Philosophy and Science Teaching. Berlin, Germany: Springer. pp. 18951925.
Vesterinen, V.M., Tolppanen, S., \& Aksela, M. (2016). Toward citizenship science education: What students do to make the world a better place? International Journal of Science Education, 38(1), 30-50.

Wang, H.H., Chen, H.T., Lin, H., Huang, Y.N., \& Hong, Z.R. (2017). Longitudinal study of a cooperation-driven, socio-scientific issue intervention on promoting students' critical thinking and self-regulation in learning science. International Journal of Science Education, 39(15), 2002-2026.

Westheimer, J., \& Kahne, J. (2004). What kind of citizen? The politics of educating for democracy. American Educational Research Journal, 41(2), 237-269.

Xiao, S. (2018). Rhetorical use of inscriptions in students' written arguments about socioscientific issues. Research in Science Education, https:// doi.org/10.1007/s11165-018-9730-y.

Yacoubian, H.A., \& Khishfe, R. (2018). Argumentation, critical thinking, nature of science and socioscientific issues: A dialogue between two researchers. International Journal of Science Education, 40(7), 796-807.

Yahaya, J.M., Nurulazam, A., \& Karpudewan, M. (2016). College students' attitudes towards sexually themed science content: A socioscientific issues approach to resolution. International Journal of Science Education, 38(7), 1174-1196.

Zangori, L., Peel, A., Kinslow, A., Friedrichsen, P., \& Sadler, T.D. (2017). Student development of model-based reasoning about carbon cycling and climate change in a socio-scientific issues unit. Journal of Research in Science Teaching, 54(10), 1249-1273.

Zeidler, D.L. (2014). Socioscientific issues as a curriculum emphasis. Theory, research, and practice. In: Lederman, N.G., \& Abell, S.K. (Eds.), Handbook of Research on Science Education. Vol. 2. Abingdon, United Kingdom: Routledge. p697-726.

Zeidler, D.L., \& Nichols, B.H. (2009). Socioscientific issues: Theory and practice. Journal of Elementary Science Education, 21(2), 49.

Zeidler, D.L., \& Sadler, T.D. (2007). The role of moral reasoning in argumentation: Conscience, character, and care. In: Erduran, S., \& Jiménez-Aleixandre, M.P., (Eds.), Argumentation in Science Education: Perspectives from Classroom-based Research. Netherlands: Springer. pp. 201-216.

Zeidler, D.L., \& Sadler, T.D. (2010). An inclusive view of scientific literacy. In: Exploring the Landscape of Scientific Literacy. United Kingdom: Routledge.

Zeidler, D.L., Sadler, T.D., Applebaum, S., \& Callahan, B.E. (2009) Advancing reflective judgment through socioscientific issues. Journal of Research in Science Teaching, 46(1), 74-101.

Zeidler, D.L., Sadler, T.D., Simmons, M.L., \& Howes, E.V. (2005). Beyond STS: A research-based framework for socioscientific issues education. Science Education, 89(3), 357-377.

Zukin, C., Keeter, S., Andolina, M., Jenkins, K., \& Carpini, M.X.D. (2006). A New Engagement? Political Participation, Civic Life, and the Changing American Citizen. Oxford: Oxford University Press. 